doi:10.4149/neo_2017_101

\title{
Current knowledge on the active form of Vitamin D synthesized in the skin and its effects on malignant melanoma
}

\section{Minireview}

B. BOLERAZSKA*, M. RABAJDOVA, I. SPAKOVA, M. MAREKOVA

Department of Medical and Clinical Biochemistry, Faculty of Medicine, P. J. Safarik University in Kosice, Kosice, Slovakia

${ }^{*}$ Correspondence: beata@moly.sk

Received April 18, 2016 / Accepted August 27, 2016

\begin{abstract}
The link between sunlight and skin cancer is a frequently discussed topic. However, ultraviolet radiation also induces the production of Vitamin D in the body. Keratinocytes and their ability to synthesize the active form of Vitamin D, which is consumed at the place of its origin in the skin, have a unique place in this discussion. We observe a remarkable sunshinerelated paradox when we monitor the relationship between the dose of solar radiation and one type of skin cancer - malignant melanoma. Recent knowledge of the non-calcemic effects of Vitamin D, which include growth regulation, DNA repair, differentiation, apoptosis, membrane transport, metabolism, cell adhesion and oxidative stress, could help to further clarify this relationship. In this context, adjuvant Vitamin D therapy is currently being considered in patients with malignant melanoma, and this is expected to reduce tumor invasiveness and micrometastases and thus improve patient prognosis and reduce the risk of relapse.
\end{abstract}

Key words: Vitamin D, malignant melanoma, adjuvant therapy, keratinocytes

Over the last decade the so-called "sunshine vitamin" has again become a hot topic of discussion. The reasons for this are the recently gained knowledge on its noncalcemic effects in humans and the finding that serum levels of Vitamin $\mathrm{D}$, based on the results of epidemiological studies and current physiologic serum levels, are globally considered to be insufficient and are being referred to as a pandemic of Vitamin D deficiency [1]. In the context of this pandemic and the skin synthesis of the active form of Vitamin D, the following questions are raised: What effect do the reduced levels of the active form of Vitamin D or its precursors have on metabolism in the skin? Could the skin be selfsufficient in the production of Vitamin D? Can exogenous Vitamin D supplements affect the risk of developing skin diseases, in particular skin cancer? Answering these questions clearly and responsibly is not currently possible. In this article we try to summarize the latest knowledge and the relationship between the unique synthesis of the active form of Vitamin D in the skin directly and its impact on the disease malignant melanoma (MM). The basic terminology of Vitamin D is shown in Table 1.

\section{Localization of endogenous Vitamin D synthesis}

The generally known process of human endogenous Vitamin D synthesis begins in the skin after exposure to UV radiation, and its conversion to the active form occurs by hydroxylation in the liver and kidneys. A prerequisite for the course of such hydroxylation reactions is the presence of the enzymes 25-hydroxylase (CYP27A1) and 1a-hydroxylase (CYP27B1); the first enzyme is mainly active in hepatocytes and the second mainly in the proximal tubule of the kidneys. The $25(\mathrm{OH}) \mathrm{D}_{3}$ generated by the photochemical reaction represents about $90 \%$ of the circulating Vitamin D level. The other $10 \%$ comes from food sources and is referred to as ergocalciferol $\left(25(\mathrm{OH}) \mathrm{D}_{2}\right)$. 
Table 1. The basic terminology of Vitamin D

\begin{tabular}{llll}
\hline Ergocalciferol & Vitamin $\mathrm{D}_{2}$ & Plant origin \\
\hline Cholecalciferol & Vitamin $\mathrm{D}_{3}$ & Animal origin Produced in human skin \\
\hline & 25-hydroxyVitamin $\mathrm{D}$ & $25(\mathrm{OH}) \mathrm{D}$ & $\begin{array}{l}\text { Designation does not identify the origin. If desired, the origin is indicated by a number in the } \\
\text { lower index. This figure is not related to the number of hydroxyl groups (OH). }\end{array}$ \\
\hline Ercalcidiol & 25-hydroxyVitamin $\mathrm{D}_{2}$ & $25(\mathrm{OH}) \mathrm{D}_{2}$ & Predominant circulating form of Vitamin $\mathrm{D}_{2}$ \\
\hline Calcidiol & 25-hydroxyVitamin $\mathrm{D}_{3}$ & $25(\mathrm{OH}) \mathrm{D}_{3}$ & Predominant circulating form of Vitamin $\mathrm{D}_{3}$ \\
\hline Ercalcitriol & 1,25-dihydroxyVitamin $\mathrm{D}^{2}$ & $1,25(\mathrm{OH})_{2} \mathrm{D}$ & As in 25(OH)D \\
\hline Calcitriol & 1,25-dihydroxyVitamin $\mathrm{D}_{2}$ & $1,25(\mathrm{OH})_{2} \mathrm{D}_{2}$ & Active form of Vitamin $\mathrm{D}_{2}$ Short biological half-life in circulation \\
\hline
\end{tabular}

Less well known is the fact that this synthesis also runs simultaneously and in its entirety in keratinocytes, which are the only human cells with the enzymes needed for the full course of the synthesis from pro-vitamin Vitamin D (7-dehydrocholesterol) to its active form (calcitriol, 1,25(OH) $\mathrm{D}_{3}$ ) (Figure 1). Similarly, the significance and function of the active Vitamin D formed in this way is less clear [2]. Upon learning these facts, efforts have been made to assess how much active Vitamin $\mathrm{D}\left(1,25(\mathrm{OH})_{2} \mathrm{D}_{3}\right)$ the skin is able to synthesize.
Extra-renal synthesis of $1,25(\mathrm{OH})_{2} \mathrm{D}$ has been repeatedly demonstrated in anephric humans [3]. At present it is not yet clear how much of the $1,25(\mathrm{OH})_{2} \mathrm{D}_{3}$ is produced by the epidermis and actually enters into circulation. Experiments for these purposes measured the production of the active form of Vitamin D in the skin of pigs without kidneys and evaluated the extent to which this participates in the total production of $1,25(\mathrm{OH})_{2} \mathrm{D}_{3}$ in systemic circulation in the basal state and after supplementation with precursors of the active form of

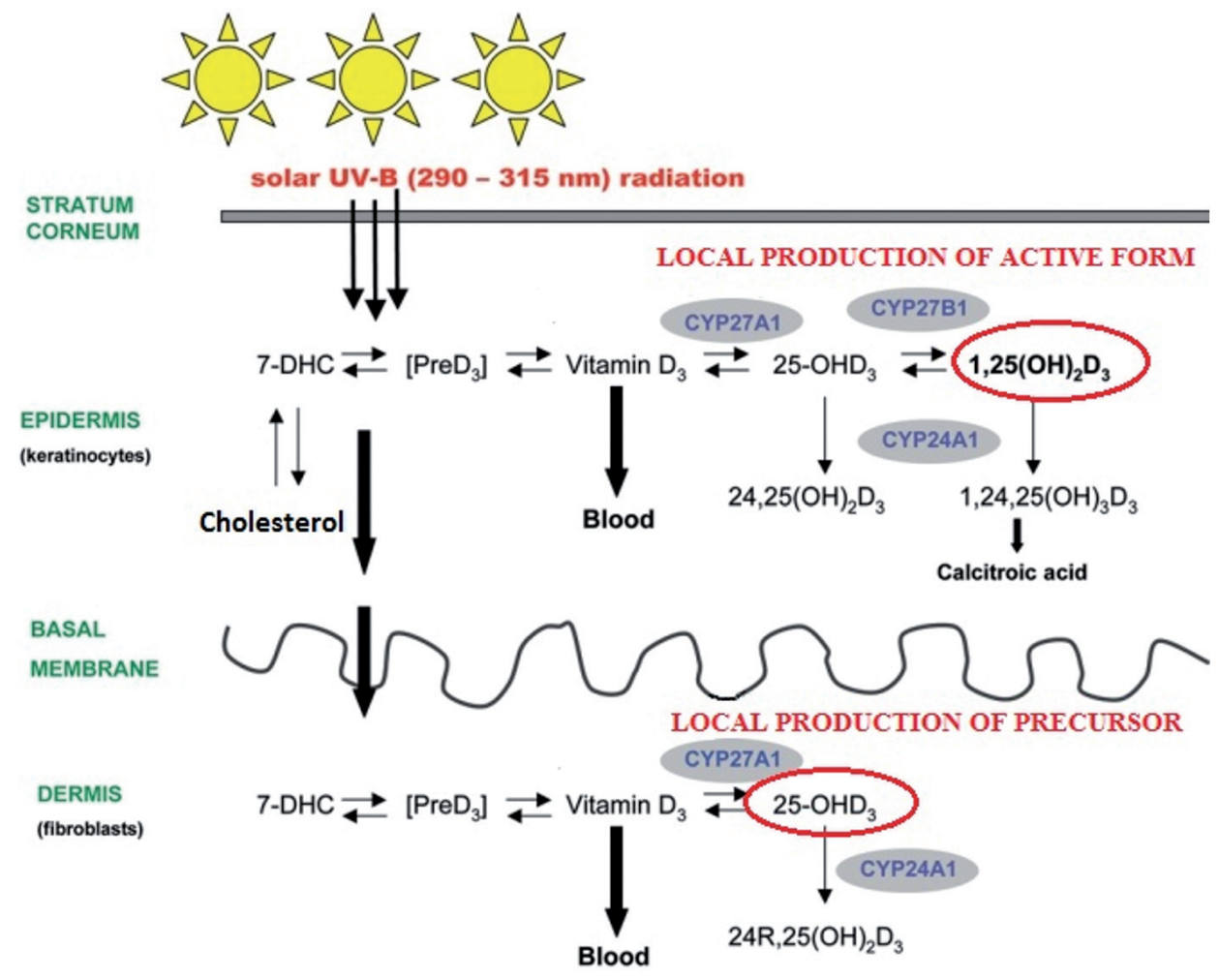

Figure 1. Skin synthesis of Vitamin D. The stratum basale and spinosum skin layers have the greatest potential for the production of Vitamin D, as they contain the highest concentration of 7-dehydrocholesterol (7-DHC, pro-Vitamin $\mathrm{D}_{3}$ ). The effects of ultraviolet radiation lead to the splitting of the $\mathrm{B}$ ring between the 9 and 10 carbon (s-cis conformation), producing a less favorable form of cis-previtamin-D3 (PreD ${ }_{3}$, pre-cholecalciferol). Subsequent rotation around the 5 th and 6 th atoms gives rise to the thermodynamically more stable s-trans conformation (cholecalciferol, Vitamin D3). Hydroxylation in the liver then produces 25 -hydroxyVitamin $\mathrm{D}_{3}\left(25(\mathrm{OH}) \mathrm{D}_{3}\right.$, calcifediol), which is then hydroxylated in the kidney to 1,25 -dihydroxyVitamin $\mathrm{D}_{3}$ $\left(1,25(\mathrm{OH})_{2} \mathrm{D}_{3}\right.$, Calcitriol, the active form of Vitamin $\left.\mathrm{D}\right)$. The only cells in the human body to contain the complete enzymatic machinery for the synthesis of the active form of Vitamin D are keratinocytes (edited by Reichrath J et al. [126]). 
Vitamin D. It was shown that only a minimal amount of the Vitamin D in systemic circulation was formed by the skin in the active form under normal conditions, but in anephric animals this proportion is increased [4]. UVB - triggered synthesis of calcitriol in human skin was demonstrated for the first time in vivo only in 2003 [5]. This means that 25(OH)D of photochemical origin, although predominant in systemic circulation, is not completely released from the skin, but a certain fraction is subjected to progressive hydroxylation directly in the keratinocytes. Fibroblasts in the skin can be a natural donor of precursors of the active form of Vitamin D, because they produce one of the necessary enzymes, 25-hydroxylase (CYP27A1), but not the other, 1a-hydroxylase (CYP27B1) [6]. The cutaneous synthesis of calcitriol $\left(1,25(\mathrm{OH})_{2} \mathrm{D}_{3}\right)$ is attributed to the effect of intracrine and/or autocrine on the keratinocytes themselves and paracrine on the adjacent cells, which may be melanocytes or malignant melanoma cells [7].

In the blood, the precursor of the active form $(25(\mathrm{OH})$ D) is almost completely bound to the Vitamin D binding protein (VDBP); only about $0.3 \%$ is free [8]. The result of this is that keratinocytes cannot utilize precursors of the active form of Vitamin D in systemic circulation and are almost entirely dependent on their own synthesis. The absence of blood supply to the epidermis also contributes to this lower utilization. Similarly, only $0.4 \%$ of the active form of Vitamin D in systemic circulation is in its free form [9]. According to the "free hormone hypothesis", it is generally accepted that it is only the free $1,25(\mathrm{OH})_{2} \mathrm{D}_{3}$, not the total amount, that controls the genomic process in keratinocytes [10]. However, its concentration in systemic circulation is far too low to induce the effects of the hormone mediated by the Vitamin D receptor (VDR) in the skin, although keratinocytes possess the VDR $[11,12]$. This is probably one of the reasons why concentrations of Vitamin D that are too high can affect metabolic processes in the skin (for example the inhibition of proliferation; stimulation of differentiation, including formation of the permeability barrier; promotion of innate immunity; and promotion of the hair follicle cycle [13], including carcinogenesis [14].

\section{General biological effects of Vitamin D in the context of malignant melanoma}

The general biological effects of Vitamin D in the context of cancer, malignant melanoma in particular, may occur at the tumor location and by passing into systemic circulation may also affect a tumor's ability to form micrometastases. The remote and local effects of Vitamin D are mainly mediated by the VDR. This is a predominantly nuclear protein which binds the active form of Vitamin D with high affinity and specificity and in turn regulates the transcription of many genes: $1,25(\mathrm{OH})_{2} \mathrm{D}$ may regulate at least 3000 genes in the human genome [15]. In addition, the sensitivity of melanoma to added 1,25-dihydroxyVitamin D3 seems to correlate with the stimulation of gene expression. For example, MeWo and SK Mel-28 melanomas were found to be sensitive to 1,25-dihydroxyVitamin D3, which also resulted in altered expression of Vitamin D-related genes. In other melanomas, such as SK Mel 5 and SK Mel 25, treatment with 1,25-dihydroxyVitamin D3 failed to induce expression of the genes and inhibition of cell growth [16].

Modulation of the target genes is carried out after the binding of calcitriol to the VDR. Interaction of the RXR (Retinoid $\mathrm{X}$ receptor) to the ligand-binding domain on the VDR, the structurally conserved DNA part, is necessary for the formation of this bond. A complex consisting of the VDR, RXR and calcitriol is ready for binding to Vitamin $\mathrm{D}$ responsive elements (VDREs), regions on the DNA at various distances from the transcription start site of the gene being regulated [17]. The highest expression of this receptor has been reported in metabolically active tissues, such as the skin, intestine, kidney and thyroid. It is also expressed in tumor tissues [18]. Based on an immune-histochemical analysis of skin tissues, it was proven that expression of the VDR decreases in the following order: normal skin $>$ melanocytic nevi $>$ non-metastatic melanoma $=$ metastatic melanoma. Likewise VDR expression decreases with increasing progression of the tumor stage [19]. This receptor is also exprimated by keratinocytes to make it possible to respond to their own product - the active form of Vitamin D. Moreover, we also know that the non-genomic actions of $1,25(\mathrm{OH})_{2} \mathrm{D}_{3}$ lead to the activation of many signaling molecules, such as phospholipase C, phospholipase A2 (PLA2), phosphatidylinositol-3 kinase (PI3K) and p21ras, and the rapid generation of second messengers (Ca2+, cyclic AMP, fatty acids and 3-phosphoinositides, such as phosphatidylinositol 3,4,5 trisphosphate), accompanied by the activation of protein kinases, such as protein kinase $\mathrm{A}$, src, mitogen-activated protein (MAP) kinases, protein kinase $\mathrm{C}(\mathrm{PKC})$ and $\mathrm{Ca} 2+$-calmodulin kinase II [20, 21, 22, 23, 24].

The most important mediated biological anti-cancer effects of $1,25(\mathrm{OH})_{2} \mathrm{D}_{3}$ include the induction of cell-cycle arrest, stimulation of apoptosis and inhibition of metastasis and angiogenesis [25]. The major antiproliferative effect of $1,25(\mathrm{OH})_{2} \mathrm{D}_{3}$ is based on blocking the G1 phase of the cell cycle [26]. The up-regulation of $\mathrm{p} 21$ and $\mathrm{p} 27$ principally mediate G1 cell-cycle arrest, but in addition $1,25(\mathrm{OH})_{2} \mathrm{D}_{3}$ has also been shown to mediate G2/M cell-cycle arrest in a number of cancer cell lines $[27,28]$. In general, Vitamin D can the affect cell cycle in several ways, for example, through expression of the cyclins D1E and A, the kinases CDK 2, 4 and 6 [29], and the proteins $M y c$, Fos, Jun; In addition, it can up regulate insulin-like growth factor binding protein-3 (IGFBP3) [30], decreate and degradate prostaglandins [31] and influence the phosphorylation of retinoblastoma protein [29]. VDR loss or loss of the ability to form $1,25(\mathrm{OH}){ }_{2} \mathrm{D}_{3}$ (CYP27B1 mutations/ deletions) indirectly confirm the effects of Vitamin D, which in skin results in disruption of the epidermal differentiation process (in the epidermis), resulting in hyperproliferation of 
the basal layer. These findings have been proven in a relatively short period [32].

In the development of malignant melanoma the inflammatory reaction, which most often results in response to ongoing tumorigenesis or after exposure to UV radiation, plays an important role. Cancer-related inflammation is in general characterized by the presence of inflammatory cells at tumor sites and over expression of inflammatory mediators, such as cytokines, chemokines, prostaglandins (PGs) and reactive oxygen and nitrogen species, in tumor tissue [33, 34]. Calcitriol affects the PG pathway in general by three separate mechanisms: decreasing COX-2 expression, increasing 15-PDGH expression (an enzyme regarded as a physiological antagonist of COX-2) and reducing PG receptor levels [35,36]. Promotion of tumor angiogenesis, metastasis and invasion may be due to activate angiogenic switches under the control of vascular endothelial growth factor (VGEF) by these above-mentioned mediators $[37,38]$. Hypoxia significantly increases its production and it has been noted that Vitamin D is able to reduce VEGF expression during exposure to hypoxic conditions [39, 40]. Vitamin D can inhibit the expression of VEGF by cancer cells and decrease responses to VEGF by endothelial cell $[39,41]$. The anti-inflammatory effects of Vitamin D can be mediated through up regulation of the expression of mitogenactivated protein kinase phosphatase-5 (MKP5), which in turn reduces the level of expression of pro-inflammatory cytokines and also their biological activity [31]. Incorrect regulation of NF- $\kappa B$, a known protein complex that among other things controls DNA transcription, cytokine production and cell survival, has been repeatedly linked to cancer development, notably in the process leading from inflammation to carcinogenesis [42]. In contrast to normal cells, many cancer cells have elevated levels of active NFKB. Calcitriol is able to block NFkB activation [43], and inhibition of NF- $\kappa B$ activation appears to be a very promising option for anti-cancer therapies, including for melanoma [44].

Vitamin D can induce the apoptosis of cancer cells at the gene level through the inhibition of the anti-apoptotic gene Bcl-2 [45] and the induction of pro-apoptotic genes such as DAP (death-associated protein-3), CFKAR (cyspase 8 apoptosis-related cystein peptidase) and FADD (Fas-associated death domain) [46] and can actually stimulate the pro-autophagic gene beclin-1 [47]. In addition, calcitriol enhances activation of the pro-apoptotic proteins Bax and $\mu$-calpain $[48,49,50,51]$. The ability to activate apoptosis is definitely one of the most important functions of tumor protein p53, and disruption of this process can promote tumor progression and chemoresistance. Protein p53 serves as a regulator of the apoptotic process that can modulate key control points in both extrinsic and intrinsic pathways. It has been shown in several cancer cell lines that the mechanism of Vitamin D-induced apoptosis varies with the cell type and can be mediated by both the p53-dependent as well as independent pathways $[52,53]$. The functional convergence between p53 family and VDR signaling, which occurs in the dermis, is probably an evolutionary adaptation to counterbalance the conflicting physiological requirements of Vitamin D synthesis and genome protection to protect against genotoxic insults derived from either the environment or local inflammation [54].

\section{Position of Vitamin D in the tumor microenvironment of malignant melanoma}

The melanoma microenvironment includes principally the endothelium, inflammatory cells and keratinocytes. Under normal tissue homeostasis, melanocytes in the skin dwell on the basement membrane in close contact with keratinocytes, which direct their behavior and growth through an intricate system of growth factors and cell-adhesion molecules [55]. Keratinocytes are clearly involved in crosstalk with malignant melanocytes. These interactions between keratinocytes and melanocytes in relation to the local production of the active form of Vitamin D have not yet been examined in detail. Similar to keratinocytes, the autonomous local production of the active form of Vitamin $\mathrm{D}\left(1,25(\mathrm{OH})_{2} \mathrm{D}_{3}\right)$ and also expression of the VDR [56] have also been found to occur in melanocytes. Melanoma cells are also capable of synthesizing $1,25(\mathrm{OH})_{2} \mathrm{D}_{3}$ from $25(\mathrm{OH}) \mathrm{D}_{3}$ and expressing the VDR, and on exposure to $1,25(\mathrm{OH})_{2} \mathrm{D}_{3}$ they respond by slowing their proliferation [57]. Both types of cells lack the complete enzymatic equipment for total synthesis of Vitamin D, and therefore they are dependent on the supply of intermediates or the active product directly from their surrounding environment. Data obtained from in vitro experiments proved that the active form of $\mathrm{Vi}-$ tamin $\mathrm{D}\left(1,25(\mathrm{OH})_{2} \mathrm{D}_{3}\right)$ was able to stimulate the maturation of melanocytes, presumably through stimulation of tyrosinase activity (a key enzyme in melanin biosynthesis) $[58,59]$. It also protected the cells from apoptosis and increased expression of the VDR [60, 61].

The multistep process that leads to neoplastic transformation includes genome instability, avoiding immune attack, evading growth suppressors, enabling replicative immortality, resisting cell death, sustaining proliferative signaling (including angiogenesis), activating invasion and metastasis and deregulating cellular energetics and tumor promoting inflammation [62]. The response to inflammation is pro-oxidant, with production of reactive oxygen species (ROS) and reactive nitrogen intermediates (RNI). The result is redox dysregulation, which promotes alteration in the signaling and leads to secretion of chemokines, cytokines and prostaglandins related to the onset of neoplasia [63]. Most studies are performed in vitro by growing isolated melanoma cells in monocultures under conditions that cannot accurately imitate the appropriate tumor microenvironment [64]. In some, but not all melanoma cell cultures, anti-proliferative and pro-differentiative effects of Vitamin D and its precursors were demonstrated [57, 65, 66]. The active form of Vitamin $\mathrm{D}\left(1,25(\mathrm{OH})_{2} \mathrm{D}_{3}\right)$ inhibited the invasive behavior of tumor and angiogenesis in melanoma cell lines [67] and also suppressed the growth of human 
melanoma transferred as xenografts to immunosuppressed mice that express the VDR. However, this did not occur in MM cell lines, which were modified to not express the VDR [68]. Subsequently, it was shown that certain melanoma cell lines were resistant to the effects of Vitamin D. These cell lines exhibited a decreased expression of mRNA for the gene encoding the VDR or increased activity of the enzyme 24-hydroxylase (CYP24A1), which is an enzyme regulating excess of Vitamin D [56, 66, 69]. Melanoma cell activity is, in addition to other factors, dependent on the activity of tumor-infiltrating inflammatory cells and fibroblasts. The melanoma cells are able to influence the differentiation pattern of keratinocytes by production of FGF-2, VEGE A, IL-8, and CXCL-1. The reciprocal activity of keratinocytes to melanoma cells needs further research [70]. The potential role of melanoma cell-activated keratinocytes on tumor biology, including metastasation, should be verified [70].

A long time ago it was assumed that mortality due to cancer could be reduced by mild unprotected exposure to UV radiation, or by oral substitution of Vitamin D3 [71]. Exposure to ultraviolet light results in augmented IL-1, IL-6, IL-8 and TNF- $\alpha$ production by human keratinocytes $[72,73]$. Topical application of $1,25(\mathrm{OH}) 3 \mathrm{D} 3$ to the UV-irradiated skin of a human subject reduced the "sunburn cells" numbers [74]. The term "sunburn cells" is used for apoptotic keratinocytes with a pyknotic nucleus and eosinophilic cytoplasm [75]. One of the demonstrated abilities of Vitamin D is optimization of DNA repair, which protects against UV-induced mutations, the most common cause of skin cancer in humans. A number of epidemiological studies have shown a link between Vitamin D status and different types of cancers [76, 77], and some of them have confirmed this hypothesis, showing the protective effect of Vitamin D against progression and overall mortality in a large group of different cancer types [78]. Interestingly, since UV exposure is the main risk factor for melanoma, Vitamin D synthesis associated with UV exposure may also serve as a protective factor $[79,80]$.

\section{Behind all this hides the Sun}

Life on Earth originated in harmony with the Sun, and therefore Vitamin D should be considered as one of the oldest hormones evolutionarily. It is photosynthesized in all forms of life, from phytoplankton (750 million years ago) to mammals. While Vitamin D's role in calcium and bone metabolism makes it clear why terrestrial animals need it, it is less clear why marine and fresh water invertebrates and plants generate Vitamin D [81]. UV light from sun exposure has several well-known effects in the skin: UVA induces DNA damage through increasing the level of reactive oxygen species (ROS), but importantly UVB light also catalyzes the conversion of 7-dehydrocholesterol to 25(OH)-D and even induces the expression of VDR. VDR probably represent an adaptation of the skin to UV exposure, coupling the paramount importance of initiating $1,25(\mathrm{OH})_{2} \mathrm{D}_{3}$ synthesis with protection of cell and tissue integrity [82]. Thus, VDR actions are able to maximize UV-initiated synthesis of $1,25(\mathrm{OH})_{2} \mathrm{D}_{3}$, whilst controlling the extent of local inflammation that can result from sun exposure. Inflamed tissues contain more ROS, which in turn can damage DNA and prevent the proper function of DNA-repair machinery. Also, the induction of cytokines and growth factors associated with inflammation act to increase the proliferative potential of the cells. The above-mentioned NF- $\kappa \mathrm{B}-\mathrm{a}$ key mediator of inflammation - and the VDR attenuate this process by negatively regulating NF- $\kappa \mathrm{B}$ signaling [83]. The normally protective role of inflammation that occurs under other conditions is lost through VDR-mediated suppression, but it is compensated for by the induction of a cohort of antimicrobial and antifungal genes. The induction of antimicrobials not only prevents infection in damaged tissue but can be cytotoxic for cells with increased levels of anion phospholipids within their membranes, a common feature of transformed cells [84]. The effects of $1,25(\mathrm{OH})_{2} \mathrm{D}_{3}$ have been expanded to include its impact on nucleotide excision repair (NER), the main system of DNA repair, which is induced after exposure to ultraviolet light. Recognition of the damage with the help of specific ("Damage Sensing") proteins leads to the removal of the short, single-stranded DNA segment that contains the lesion. Then, as part of the NER mechanism, the synthesis of a complementary strand of DNA and ligation follow [85]. It is likely that $1,25(\mathrm{OH})_{2} \mathrm{D}_{3}$ can stimulate NER, leading to more efficient removal of carcinogenic UV-induced photoproducts and other lesions involved in skin cancer transformation [86]. In in vivo studies in hairless mice (Skh: HR1) with skin cancer induced by UV radiation, topical treatment with $1,25(\mathrm{OH})_{2} \mathrm{D}_{3}$ post-exposure appeared to reduce the amount of DNA damage as measured by the number of cyclobutane pyrimidine dimers (CPDs) formed [87]. A proposal to implement individualized administration of Vitamin D based on the analysis of the NER system for the purpose of prevention/treatment of skin cancers in today's world of personalized medicine has also emerged in this area. It has been noted by Pawlovska et al. (2016) and is based on isolation of keratinocytes from an individual and subsequent analyzing of the NER system (functional assay), on the basis of which the dosage of Vitamin D3 supplementation would be determined [86]. UV radiation also causes degradation of generated Vitamin D, and therefore it has a regulatory effect on its creation while almost completely eliminating the possibility of a Vitamin D overdose caused by sun exposure [88]. The mere formation of Vitamin D is influenced by numerous internal (e.g. skin thickness with its associated quantity of precursor, ethnicity, congenital enzyme activity) and external factors e.g. way of dressing, geographic location, number of sunny days a year), but UV rays have the most significant impact on its creation, namely by photodegradation [89].

The most widespread current hypothesis on the origin of malignant melanoma (MM) is its development as a result of sunburning in people who spend the vast majority of time indoors, and who during a holiday are subjected to excessive sun exposure $[90,91,92,93]$. This results in local damage to DNA 
and immunosuppression, which leads to an increased risk of malignant melanoma after some time on the intermittently covered parts of the body $[94,95]$. A rising incidence of malignant melanoma is being continuously recorded globally, but this trend seems to be closely related to screening campaigns in the interests of public health, and their implementation has contributed to an artificial increase in the incidence of the disease in many countries. This means that changes in behavior towards sunlight are not one of the main causes of the increased incidence. Another argument that weakens the harmful effect of UV light in connection with malignant melanoma is that melanoma is a tumor that behaves similarly within similar ethnic groups worldwide, despite the varying intensity of UV radiation. The anticipated reduction in the average age of onset of the disease has not occurred and no changes have been recorded even in the most common localizations of malignant melanoma [96].

The incidence of MM on skin intermittently exposed to sunlight is significantly less common in people who work outdoors than in people working indoors [97]. This finding may mean a lower probability of sunburn in humans who are often exposed to the sun, but an alternative hypothesis is that these people are less likely to be Vitamin D deficient. Another aspect being considered is the different pathogenesis of melanomas which occur in people with a higher risk of actinic skin damage (skin phototype). In 2010 an extensive study was conducted in the UK whose results showed a more frequent occurrence of malignant melanoma in phenotypes with a tendency to sunburn and confirmed skin burning before the age of 20 [93]. In contrast, another current hypothesis regarding malignant melanoma is risk reduction due to photoadaptation after periodic exposure to solar radiation, which simultaneously increases the synthesis of Vitamin D. Some data even indicate a possible photoprotective effect of Vitamin D itself [54, 74, 98]. Vitamin D could be a mediator through which sunburn results in systemic immunosuppression [98]. Vitamin D was found to cause a reduction in UVA-induced skin damage and also a reduction in UV-induced immunosuppression in studies performed on mice models in vitro and also on human skin [99]. These effects of Vitamin D were also demonstrated when Vitamin D analogues were applied topically to irradiated skin [74].

In 2005, a study was published which monitored the presence of elastosis (dermal post-solar skin damage) in samples of malignant melanoma. The results indicated that the presence of dermal damage to the skin in the excision of malignant melanoma meant a better prognosis for the patient [100]. One explanation for this finding is that chronic sun damage can cause a less aggressive form of malignant melanoma. Another possible explanation is that the presence of higher levels of Vitamin D in individuals exposed to the sun more often can protect against the formation of relapse, even in terms of the link between UV radiation and the etiology of this disease [101].

Thus, if we assume that the anti-proliferative effect of Vitamin $\mathrm{D}$ is important for modifying the development of the disease in patients with malignant melanoma, the patient's prognosis would be favorable in countries with a higher intensity of solar radiation compared to countries where it is lower. The reality is that the prospects for patients diagnosed in Australia are better than those who were diagnosed in the UK. Both populations are genetically similar, because the Australian population is largely British in origin [102]. An extensive retrospective study of data from 1993 to 2003 comparing the 5-year survival of patients in Yorkshire, in the UK, $(n=4170)$ and New South Wales, in Australia, $(n=30520)$ showed a relatively lower risk of death in New South Wales. This was attributed in particular to the more frequent occurrence of thinner tumor types (tumors with thickness $<$ or $=$ $1 \mathrm{~mm}$ ) according to the Breslow classification in this area, which is due to the detection of tumors at an earlier stage. At the same time, Australian patients had higher average values of Vitamin D [103]. Analysis of patient data purely from the United Kingdom has shown that higher serum concentrations of 25-hydroxyVitamin D at the time of diagnosis are more frequent in thinner tumor types. The conclusions of these two studies was that the difference between these countries was based on different tumor thickness according to Breslow at the time of diagnosis, and the thickness was associated with the serum level of Vitamin D [104]. Comparing two groups with a similar genetic background but a different environment is still the subject of ongoing studies looking to elucidate the circumstances of malignant melanoma. It is not yet clear whether these findings reflect the benefits of continuous exposure to solar radiation and connected to the use of Vitamin D or a different pathogenesis of melanomas which occurs in people who are at increased risk of actinic skin damage [105].

\section{Assessment of Vitamin D status}

Due to the presence of several forms of Vitamin $D$ and their different binding strengths to VDBP, Vitamin D is a difficult analyte to determine. So-called Total Vitamin D $\left(25-\mathrm{OHD}_{2}\right.$ $+25 \mathrm{OHD}_{3}$ ) in blood serum is currently recommended as the best indicator of Vitamin D in the human body due to its long biological half-life of over 250 hours (2-3 weeks) [106]. Assessing the effects of Vitamin D in skin tissue is based on the assumption that the serum level reflects its production in the skin $[107,108]$. The proportion of Vitamin D obtained from food increases in importance during the winter months. As indicated above, part of this production is released into systemic circulation, but a certain part is always dependent on reactions leading to the formation of the active form of Vitamin D directly in skin tissue. Based on this relationship, it is thought that the serum level of Vitamin D is predominantly a reflection of its formation in the skin in places exposed to UV light, and thus the local skin production of the active form of Vitamin D.

As for patients with a confirmed diagnosis of MM or at a higher risk for this disease, to date no optimal serum level of Vitamin D has yet been definitively determined [109]. Field 
and Newton-Bishop (2011) proposed a value between 70 and $100 \mathrm{nmol} / \mathrm{L}(28-40 \mathrm{ng} / \mathrm{mL})$ in patients with a pre-established diagnosis, because studies show that higher serum levels of Vitamin D may in general affect tumor cell proliferation [110]. In a prospective cohort study performed in 872 patients, higher serum levels of Vitamin D at the time of diagnosis were associated with a lower value of the Breslow thickness classification (penetration depth measured in millimeters) of malignant melanoma [104]. There were further results which showed a lower risk of relapse in MM patients supplemented with Vitamin D compared to healthy controls [111]. Moreover, the progression of the disease is associated with a statistically significant reduction in serum levels of Vitamin D [79].

\section{Vitamin D therapy in malignant melanoma - a potential adjuvant therapy}

Until recently, recommended doses of Vitamin D were related to its effects on bones and the metabolism of calcium and phosphorus. Currently, based on meta-analyses, suitable doses and values are also being established for patients suffering from or at risk of cancer (Table 2) [105].

The theoretical treatment options of MM with Vitamin $\mathrm{D}$ include the induction of its formation by UV irradiation, a topical application and oral administration in the form of supplements. The specific food sources of Vitamin D mean that a completely alimentary form of intake can never meet daily needs [112]. In the first option, the cutaneous synthesis of the active form of Vitamin D occurs, and its effects in this case are the most comprehensive. The optimal period of exposure to UV radiation, which would minimize the damage to the DNA and would mean maximum benefit in the form of synthesis of Vitamin D, remains an unanswered question. Accordingly, peroral administration is still considered the safest option, but possibly undesirable systemic effects can be expected. What still remains unclear is whether the beneficial effects of Vitamin D produced in the skin are larger than those that follow taking an equivalent amount of Vitamin D in the form of supplements. Analogues of Vitamin D with a short side chain or completely lacking one are characterized by a lower hypercalcemic activity $[113,114$, 115]. These analogues proved to be more effective at inhibiting the cell proliferation of malignant melanoma compared to normal melanocytes and keratinocytes [116].

Based on recent research work, adjuvant treatment with Vitamin D is suggested in the III. and IV. stages of malignant melanoma together with any oncological treatment. This is taken from evidence showing a higher incidence of advanced disease stages and disease progression in patients with Vitamin D deficiency. In stages I and II of the disease the prophylactic use of very high doses of Vitamin D $(50,000$ to $100,000 \mathrm{IU}$ per day) are recommended if the serum level of Vitamin D is low $(<30 \mathrm{ng} / \mathrm{ml})$. After reaching a serum level between $50-100 \mathrm{ng} / \mathrm{ml}$, the dose is reduced to $4000-6000 \mathrm{IU}$,
Table 2. Serum concentration of Vitamin D and health effects

\begin{tabular}{ll}
\hline $\begin{array}{l}\text { Vitamin D level } \\
(\mathbf{n g} / \mathbf{m L})\end{array}$ & Benefits \\
\hline$>10$ & Avoid rickets and osteomalacia \\
$>20$ & Suppress parathormone levels \\
$>30$ & Increased intestinal calcium absorption \\
$>50$ & Improved physical performance, especially in the elderly \\
$50-80$ & Optimal level according to the Vitamin D council \\
\hline
\end{tabular}

(http://www.lifetime-weightloss.com/blog/2015/10/29/could-vitamin-d-helpyou-avoid-the-flu.html as accessed on April 18, 2016)

while serum calcium levels are simultaneously monitored. This approach could be particularly beneficial for patients at high risk of metastasis (mitotic active melanomas in the vertical growth phase, which are relatively thick, or with positive sentinel lymph node) [117].

\section{Conclusion}

Currently, Vitamin D is regarded as a fat-soluble steroid hormone whose genomic effects are mediated through binding to a specific receptor. Non-classical, pleiotropic effects are now attributed to Vitamin D alongside its confirmed, classical effects in relation to the preservation of healthy bones. These non-classical effects are currently being observed in autoimmune diseases [118], cardiovascular diseases [119], hypersensitivity to infections [120], the development of cancer [121], but also over the course of physiological aging [122]. Their role in skin cancer and notably in malignant melanoma is much more controversial. The reason is mainly in the skin's ability to generate the active form of Vitamin $\mathrm{D}\left(1,25(\mathrm{OH})_{2} \mathrm{D}_{3}\right)$ via keratinocytes and its local paracrine effects on the adjacent cells and therefore melanocytes and malignant melanoma cells.

Epidemiological studies have repeatedly drawn attention to the relationship between exposure to sunlight and the risk of malignant melanoma, but the nature of this relationship appears to be complex. The classical relationship of dose and risk - the higher the dose, the higher the risk - does not apply. The dominant risk factor is sunburn and not cumulative sun exposure. The process of sunburn likely leads to the suppression of immune reactions, which is subsequently involved in the course of malignant melanoma carcinogenesis. The hypothesis is that intense sun exposure induces both genetic changes, resulting in tumour antigenicity, and the inability of the immune system to detect those changes [123].

Epidemiological researchers are increasingly coming to a consensus on the role of Vitamin D in the prevention of many types of cancer, the most discussed being prostate, breast and colon cancer [124]. It is believed that Vitamin D itself is also able to influence the process of carcinogenesis in malignant melanoma, and this will probably include invasion and the formation of early metastasis. Higher serum levels of Vitamin D have been reported in patients with thinner types of 
$\mathrm{MM}$, and their findings at the time of diagnosis were associated with a better prognosis and a lower risk of relapse.

However, the anti-cancer effects of Vitamin D in this disease may be limited by the different mechanisms of resistance of tumor cells to the effects of Vitamin D (reduction in the bioavailability of Vitamin D, suppression of VDR expression and changes in the expression of VDR coregulators) [125]. Investigations of these mechanisms will probably further extend the treatment and prevention options of malignant melanoma as well as other malignancies.

\section{References}

[1] HOLICK MF. The Vitamin D deficiency pandemic and consequences for nonskeletal health: mechanisms of action, $\mathrm{Mol}$ Aspects Med 2008; 29: 361-368. http://dx.doi.org/10.1016/j. mam.2008.08.008

[2] LEHMANN B, RUDOLPH T, PIETZSCH J, MEURER M. Conversion of Vitamin D3 to 1a,25-dihydroxyVitamin D3 in human skin equivalents. Exp Dermatol 2000; 9: 97-103. http://dx.doi.org/10.1034/j.1600-0625.2000.009002097.x

[3] LAMBERT PW, STERN PH, AVIOLI RC, BRACKETT NC, TURNER RT et al. Evidence for extrarenal production of 1 alpha ,25-dihydroxyVitamin D in man., J Clin Invest 1982; 69: 722-725. http://dx.doi.org/10.1172/JCI110501

[4] BIKLE DD, HALLORAN BP, RIVIERE JE. Production of 1,25 dihydroxyVitamin D3 by perfused pig skin. J Invest Dermatol 1994; 102: 796-798. http://dx.doi.org/10.1111/1523-1747. ep12378190

[5] LEHMANN B, SAUTER W, KNUSCHKE P, DRESSLER S, MEURER M. Demonstration of UVB-induced synthesis of 1 alpha, 25-dihydroxyVitamin D3 (calcitriol) in human skin by microdialysis. Arch Dermatol Res 2003; 295: 24-28.

[6] VANTIEGHEM K, DEHAES P, BOUILLON R, SEGAERT S. Cultured fibroblasts produce non-active Vitamin D metabolites that can be activated by cultured keratinocytes. In: Abstracts twelfth workshop on Vitamin D, July 6-10, 2003; 27.

[7] MORRIS HA, ANDERSON PH. Autocrine and paracrine actions of Vitamin D. Clin Biochem Rev 2010; 31: 129-138.

[8] BIKLE DD, GEE E, HALLORAN B, KOWALSKI MA, RYZEN E, HADDAD JG. Assessment of the free fraction of 25-hydroxyVitamin D in serum and its regulation by albumin and the Vitamin D-binding protein. J Clin Endocrinol Metab 1986; 63, 954-959. http://dx.doi.org/10.1210/jcem-63-4-954

[9] BIKLE DD, GEE E. Free, and not total 1,25-dihydroxyVitamin D regulates 25 - hydroxyVitamin D metabolism by keratinocytes. Endocrinology 1989; 124: 649-654. http://dx.doi. org/10.1210/endo-124-2-649

[10] MENDEL CM. The free hormone hypothesis: a physiologically based mathematical model. Endocr Rev. 1989; 10: 232-274. http://dx.doi.org/10.1210/edrv-10-3-232

[11] MATSUMOTO K, AZUMA Y, KIYOKI M, OKUMURA H, HASHIMOTO K et al. Involvement of endogenously produced 1,25-dihydroxyVitamin D-3 in the growth and differentiation of human keratinocytes. Biochim Biophys Acta 1991; 1092: 311-318. http://dx.doi.org/10.1016/S0167-4889(97)90006-9
[12] PRYSTOWSKY JH, MUZIO PJ, SEVRAN S, CLEMENS TL. Effect of UVB phototherapy and oral calcitriol (1,25-dihydroxyVitamin D3) on Vitamin D photosynthesis in patients with psoriasis. J Am Acad Dermatol 1996; 35: 690-695. http:// dx.doi.org/10.1016/S0190-9622(96)90722-7

[13] BIKLE DD. Vitamin D metabolism and function in the skin. Mol Cell Endocrinol 2011; 347: 80-89. http://dx.doi. org/10.1016/j.mce.2011.05.017

[14] WELSH J. Cellular and molecular effects of Vitamin D on carcinogenesis. Arch Biochem Biophys 2012; 523: 107-114. http://dx.doi.org/10.1016/j.abb.2011.10.019

[15] HAUSSLER MR, JURUTKA PW, MIZWICKI M, NORMAN AW. Vitamin D receptor (vdr)-mediated actions of 1a,25(OH)2Vitamin D3: Genomic and non-genomic mechanisms. Best Pract Res Clin Endocrinol Metab 2011; 25: 543-559. http://dx.doi.org/10.1016/j.beem.2011.05.010

[16] SZYSZKA P, ZMIJEWSKI MA, SLOMINSKI AT. New Vitamin $\mathrm{D}$ analogs as potential therapeutics in melanoma. Expert Rev Anticancer Ther 2012; 12: 585-599. http://dx.doi. org/10.1586/era.12.40

[17] WHITFIELD GK, HSIEH JC, JURUTKA PW, SELZNICK SH, HAUSSLER CA et al. Genomic actions of 1,25-dihydroxyVitamin D3. J Nutr 1995; 125: 1690S-1694.

[18] NORMAN AW. Minireview: Vitamin D receptor: new assignments for an already busy receptor. Endocrinology 2006; 147: 5542-5448. http://dx.doi.org/10.1210/en.2006-0946

[19] BROŻYNA AA, JOZWICKI W, JANJETOVIC Z, SLOMINSKI AT. Expression of Vitamin D receptor decreases during progression of pigmented skin lessions. Hum Pathol 2011; 42: 618-631. http://dx.doi.org/10.1016/j.humpath.2010.09.014

[20] FLEET JC. Rapid, membrane-initiated actions of 1,25 dihydroxyVitamin D: What are they and what do they mean? J Nutr 2004; 134: 3215-3218.

[21] DOROUDI M, SCHWARTZ Z, BOYAN BD. Membranemediated actions of 1,25-dihydroxy Vitamin D3: A review of the roles of phospholipase $\mathrm{A} 2$ activating protein and $\mathrm{Ca}(2+) /$ calmodulin-dependent protein kinase II. J. Steroid Biochem Mol Biol 2015; 147: 81-84. http://dx.doi.org/10.1016/j. jsbmb.2014.11.002

[22] DWIVEDI PP, HII CS, FERRANTE A, TAN J, DER CJ et al. Role of MAPkinases in the 1,25-dihydroxyVitamin D3induced transactivation of the rat cytochrome P450C24 (CYP24) promoter. Specific functions for ERK1/ERK2 and ERK5. J Biol Chem 2002; 277: 29643-29653. http://dx.doi. org/10.1074/jbc.M204561200

[23] NUTCHEY BK, KAPLAN JS, DWIVEDI PP, OMDAHL JL, FERRANTE A et al. Molecular action of 1,25-dihydroxyVitamin D3 and phorbol ester on the activation of the rat cytochrome P450C24 (CYP24) promoter: Role of MAP kinase activities and identification of an important transcription factor binding site. Biochem J 2005; 389: 753-762. http://dx.doi. org/10.1042/BJ20041947

[24] DWIVEDI PP, GAO XH, TAN JC, EVDOKIOU A, FERRANTE A at al. A role for the phosphatidylinositol 3-kinase-Protein kinase C zeta-Sp1 pathway in the 1,25-dihydroxyVitamin D3 induction of the 25-hydroxyVitamin D3 24-hydroxylase gene in human kidney cells. 
Cell Signal 2010; 22: 543-552. http://dx.doi.org/10.1016/j. cellsig.2009.11.009

[25] HOLICK MF. Vitamin D deficiency. N Engl J Med. 2007; 357: 266-281. http://dx.doi.org/10.1056/NEJMra070553

[26] JENSEN SS, MADSEN MW, LUKAS J, BINDERUP L, BARTEK J. Inhibitory effects of 1a,25-dihydroxyVitamin $\mathrm{D}(3)$ on the $\mathrm{G}(1)-\mathrm{S}$ phase-controlling machinery. Mol Endocrinol 2001; 15: 1370-1380.

[27] AKUTSU N, LIN R, BASTIEN Y, BESTAWROS A, ENEPEKIDES DJ et al. Regulation of gene Expression by 1alpha,25-dihydroxyVitamin D3 and Its analog EB1089 under growth-inhibitory conditions in squamous carcinoma Cells Mol Endocrinol 2001; 15: 1127-1139.

[28] JIANG F, LI P, FORNACE AJ JR, NICOSIA SV, BAI W. G2/M arrest by 1,25-dihydroxyVitamin D3 in ovarian cancer cells mediated through the induction of GADD45 via an exonic enhancer. J Biol Chem 2003; 278: 48030-48040. http://dx.doi. org $/ 10.1074 / \mathrm{jbc} . \mathrm{M} 308430200$

[29] BOUILLON R, EELEN G, VERLINDEN L, MATHIEU C, CARMELIET G et al. Vitamin D and cancer. J. Steroid Biochem Mol Biol 2006; 102: 156-162. http://dx.doi. org/10.1016/j.jsbmb.2006.09.014

[30] BOYLE BJ, ZHAO XY, COHEN P, FELDMAN D. Insulin-like growth factor binding protein-3 mediates 1a,25dihydroxyVitamin D3 growth inhibition in the LNCaP prostate cancer cell line through p21/WAF1. J Urol 2001; 165: 13191324. http://dx.doi.org/10.1016/S0022-5347(01)69892-6

[31] MORENO J, KRISHNAN AV, SWAMI S, NONN L, PEEHL DM et al. Regulation of prostaglandin metabolism by calcitriol attenuates growth stimulation in prostate cancer cells. Cancer Res 2005; 65: 7917-7925.

[32] ELLISON TI, SMITH MK, GILLIAM AC, MACDONALD PN. Inactivation of the Vitamin D receptor enhances susceptibility of murine skin to UV-induced tumorigenesis. J Invest Dermatol 2008; 128: 2508-2517. http://dx.doi.org/10.1038/jid.2008.131

[33] ALLAVENA P, GARLANDA C, BORRELLO MG, SICA A, MANTOVANI A. Pathways connecting inflammation and cancer. Curr Opin Genet Dev 2008; 18: 3-10. http://dx.doi. org/10.1016/j.gde.2008.01.003

[34] MANTOVANI A, ALLAVENA P, SICA A, BALKWILL F. Cancer-related inflammation. Nature 2008; 454: 436-444. http://dx.doi.org/10.1038/nature07205

[35] MORENO J, KRISHNAN AV, FELDMAN D. Molecular mechanisms mediating the anti-proliferative effects of Vitamin D in prostate cancer. J Steroid Biochem Mol Biol 2005; 97: 31-36. http://dx.doi.org/10.1016/j.jsbmb.2005.06.012

[36] KRISHNAN AV, SRINIVAS S, FELDMAN D. Inhibition of prostaglandin synthesis and actions contributes to the beneficial effects of calcitriol in prostate cancer. Dermatoendocrinol 2009; 1: 7-11. http://dx.doi.org/10.4161/derm.1.1.7106

[37] ANGELO LS, KURZROCK R. Vascular endothelial growth factor and its relationship to inflammatory mediators. Clin Cancer Res 2007; 13: 2825-2830. http://dx.doi.org/10.1158/1078-0432. CCR-06-2416

[38] KUNDU JK, SURH YJ. Inflammation: gearing the journey to cancer. Mutat Res 2008; 659: 15-30. http://dx.doi. org/10.1016/j.mrrev.2008.03.002
[39] MANTELL DJ, OWENS PE, BUNDRED NJ, MAWER EB, CANFIELD AE. 1 Alpha,25-dihydroxyVitamin D(3) inhibits angiogenesis in vitro and in vivo. Circulation Research 2000; 87: 214-220. http://dx.doi.org/10.1161/01.RES.87.3.214

[40] BEN-SHOSHAN M., AMIR S., DANG DT, DANG LH, WEISMAN Y et al. 1a,25-dihydroxyVitamin D3 (Calcitriol) inhibits hypoxia-inducible factor-1/vascular endothelial growth factor pathway in human cancer cells. Mol Cancer Ther 2007; 6: 1433-1439. http://dx.doi.org/10.1158/1535-7163.MCT-06$\underline{0677}$

[41] BAO BY, YAO J, LEE YF. 1alpha, 25-dihydroxyVitamin D3 suppresses interleukin-8-mediated prostate cancer cell angiogenesis. Carcinogenesis 2006; 27: 1883-1893. http://dx.doi. org/10.1093/carcin/bgl041

[42] HOESEL B, SCHMID JA. The complexity of NF- $\kappa B$ signaling in inflammation and cancer. Mol Cancer 2013; 12: 86. http:// dx.doi.org/10.1186/1476-4598-12-86

[43] COHEN-LAHAV M, SHANY S, TOBVIN D, CHAIMOVITZ C, DOUVDEVANI A. Vitamin D decreases NFkappaB activity by increasing IkappaBalpha levels. Nephrol Dial Transplant 2006; 21: 889-897. http://dx.doi.org/10.1093/ndt/ gfi254

[44] MADONNA G, ULLMAN CD, GENTILCORE G, PALMIERI G, ASCIERTO PA., NF- $\kappa B$ as potential target in the treatment of melanoma. J Transl Med 2012; 10: 53. http://dx.doi. org/10.1186/1479-5876-10-53

[45] BLUTT SE, MCDONNELL TJ, POLEK TC, WEIGEL NL. Calcitriol-induced apoptosis in LNCaP cells is blocked by overexpression of Bcl-2. Endocrinology 2000; 141: 10-17. http://dx.doi.org/10.1210/endo.141.1.7289

[46] BIKLE DD. Vitamin D metabolism, mechanism of action, and clinical applications. Chem Biol 2014; 21:319-329. http:// dx.doi.org/10.1016/j.chembiol.2013.12.016

[47] HOYER-HANSEN M, BASTHOLM L, MATHIASEN IS, ELLING F, JAATTELA M. Vitamin D analog EB1089 triggers dramatic lysosomal changes and Beclin 1-mediated autophagic cell death. Cell Death Differ 2005; 12: 1297-1309. http://dx.doi.org/10.1038/sj.cdd.4401651

[48] JAMES SY, MACKAY AG, COLSTON KW. Effects of 1,25 dihydroxyVitamin D3 and its analogues on induction of apoptosis in breast cancer cells. J Steroid Biochem Mol Biol 1996; 58: 395-401. http://dx.doi.org/10.1016/0960-0760(96)00048-9

[49] DIAZ GD, PARASKEVA C, THOMAS MG, BINDERUP L, HAGUE A. Apoptosis is induced by the active metabolite of Vitamin D3 and its analogue EB1089 in colorectal adenoma and carcinoma cells: possible implications for prevention and therapy. Cancer Res 2000; 60: 2304-2312.

[50] JIANG F, BAO J, LI P, NICOSIA SV, BAI W. Induction of ovarian cancer cell apoptosis by 1,25-dihydroxyVitamin D3 through the down-regulation of telomerase. J Biol Chem 2004; 279: 53213-53221. http://dx.doi.org/10.1074/jbc. M410395200

[51] KUMAGAI T, SHIH LY, HUGHES SV, DESMOND JC, O'KELLY J et al. 19-Nor-1,25(OH)2D2 (a novel, noncalcemic Vitamin D analogue), combined with arsenic trioxide, has potent antitumor activity against myeloid leukemia. Cancer 
Res 2005; 65: 2488-2497. http://dx.doi.org/10.1158/00085472.CAN-04-2800

[52] FRIDMAN JS, LOWE SW. Control of apoptosis by p53. Oncogene 2003; 22: 9030-9040. http://dx.doi.org/10.1038/ sj.onc. 1207116

[53] CHAKRABORTI CK. Vitamin D as a promising anticancer agent. Indian J Pharmacol 2011; 43: 113-120. http://dx.doi. org/10.4103/0253-7613.77335

[54] GUPTA R, DIXON KM, DEO SS, HOLLIDAY CJ, SLATER $\mathrm{M}$ et al. Photoprotection by 1,25 dihydroxyVitamin D3 is associated with an increase in p53 and a decrease in nitric oxide products. J Invest Dermatol 2007; 127: 707-715. http://dx.doi. org/10.1038/sj.jid.5700597

[55] HAASS NK, SMALLEY KS, LI L, HERLYN M.: Adhesion, migration and communication in melanocytes and melanoma. Pigment Cell Res 2005, 18: 150-159. http://dx.doi. org/10.1111/j.1600-0749.2005.00235.x

[56] SEIFERT $M$, RECH $M$, MEINEKE V, TILGEN W, REICHRATH J. Differential biological effects of 1,25dihydroxyVitamin D3 on melanoma cell lines in vitro. J Steroid Biochem Mol Biol 2004; 89-90: 375-379. http://dx.doi. org/10.1016/j.jsbmb.2004.03.002

[57] COLSTON K, COLSTON MJ, FELDMAN D. 1,25-dihydroxyVitamin D3 and malignant melanoma: the presence of receptors and inhibition of cell growth in culture. Endocrinology 1981; 108: 1083-1086. http://dx.doi.org/10.1210/ endo-108-3-1083

[58] WATABE H, SOMA Y, KAWA Y, ITO M, OOKA S et al. Differentiation of murine melanocyte precursors induced by 1,25-dihydroxyVitamin D3 is associated with the stimulation of endothelin B receptor expression. J Invest Dermatol 2002; 119: 583-589. http://dx.doi.org/10.1046/j.1523-1747 2002.00116.X

[59] RANSON M, POSEN S, MASON RS. Human melanocytes as a target tissue for hormones: in vitro studies with 1 alpha-25, dihydroxyVitamin D3, alpha-melanocyte stimulating hormone, and beta-estradiol. J Invest Dermatol 1988; 91: 593-598. http://dx.doi.org/10.1111/1523-1747. ep12477126

[60] SAUER B, RUWISCH L, KLEUSER B. Antiapoptotic action of 1alpha,25-dihydroxyVitamin D3 in primary human melanocytes. Melanoma Res. 2003; 13: 339-347. http://dx.doi. org/10.1097/00008390-200308000-00002

[61] SERTZNIG P, SEIFERT M, TILGEN W, REICHRATH J. Activation of Vitamin D receptor (VDR) - and peroxisome proliferator-activated receptor (PPAR)-signaling pathways through $1,25(\mathrm{OH})(2) \mathrm{D}(3)$ in melanoma cell lines and other skin-derived cell lines. Dermatoendocrinol 2009; 1: 232-238. http://dx.doi.org/10.4161/derm.1.4.9629

[62] HANAHAN D, WEINBERG RA. Hallmarks of cancer: The next generation. Cell 2011; 144: 646-674. http://dx.doi. org/10.1016/j.cell.2011.02.013

[63] CAREW JS, HUANG P. Mitochondrial defects in cancer. Mol Cancer 2002; 1: 9. http://dx.doi.org/10.1186/1476-4598-1-9

[64] VILLANUEVA J, HERLYN M. Melanoma and the tumor microenvironment. Curr Oncol Rep 2008; 10: 439-446. http:// dx.doi.org/10.1007/s11912-008-0067-y
[65] EVANS SR, HOUGHTON AM, SCHUMAKER L, BRENNER RV, BURAS RR et al. Vitamin D receptor and growth inhibition by 1,25-dihydroxyVitamin D3 in human malignant melanoma cell lines. J Surg Res 1996; 61: 127-133. http:// dx.doi.org/10.1006/jsre.1996.0092

[66] REICHRATH J, RECH M, MOEINI M, MEESE E, TILGEN W et al. In vitro comparison of the Vitamin D endocrine system in 1,25( $\mathrm{OH}) 2 \mathrm{D} 3$-responsive and -resistant melanoma cells. Cancer Biol Ther 2007; 6: 48-55. http://dx.doi.org/10.4161/ cbt.6.1.3493

[67] OSBORNE JE, HUTCHINSON PE. Vitamin D and systemic cancer: is this relevant to malignant melanoma? $\mathrm{Br} J$ Dermatol 2002; 147: 197-213. http://dx.doi.org/10.1046/j.1365-2133 $.2002 .04960 . \mathrm{x}$

[68] EISMAN JA, BARKLA DH, TUTTON PJ. Suppression of in vivo growth of human cancer solid tumor xenografts by 1,25-dihydroxyVitamin D3. Cancer Res 1987; 47: 21-25.

[69] ALBERTSON DG, YLSTRA B, SEGRAVES R, COLLINS C, DAIRKEE SH et al. Quantitative mapping of amplicon structure by array CGH identifies CYP24 as a candidate oncogene. Nat Genet 2000; 25, 144-146. http://dx.doi. org/10.1038/75985

[70] KODET O, LACINA L, KREJČÍ E, DVOŘÁNKOVÁ B, GRIM $\mathrm{M}$ et al. Melanoma cells influence the differentiation pattern of human epidermal keratinocytes. Mol Cancer 2015; 14: 1. http://dx.doi.org/10.1186/1476-4598-14-1

[71] AINSLEIGH HG. Beneficial effects of sun exposure on cancer mortality. Prev Med 1993 22: 132-140. http://dx.doi. org/10.1006/pmed.1993.1010

[72] ANSEL JC, LUGER TA, GREEN I. The effect of in vitro and in vivo UV irradiation on the production of ETAF activity by human and murine keratinocytes. J Invest Dermatol 1983; 81: 519-523. http://dx.doi.org/10.1111/1523-1747.ep12522862

[73] KONDO S, KONO T, SAUDER DN, MCKENZIE RC. IL-8 gene expression and production in human keratinocytes and their modulation by UVB. J Invest Dermatol 1993; 101: 690-694. http://dx.doi.org/10.1111/1523-1747.ep12371677

[74] DAMIAN DL, KIM YJ, DIXON KM, HALLIDAY GM, JAVERI A et al. Topical calcitriol protects from UV-induced genetic damage but suppresses cutaneous immunity in humans. Exp Dermatol 2010; 19: 23-30. http://dx.doi.org/10.1111/j.16000625.2009.00955.X

[75] SHEEHAN JM, YOUNG AR. The sunburn cell revisited: an update on mechanistic aspects. Photochem Photobiol Sci 2002; 1: 365-377. http://dx.doi.org/10.1039/b108291d

[76] FREEDMAN DM, LOOKER AC, CHANG SC, GRAUBARD BI. Prospective study of serum Vitamin D and cancer mortality in the United States. J Natl Cancer Inst 2007; 99: 1594-1602. http://dx.doi.org/10.1093/jnci/djm204

[77] AHN J, PETERS U, ALBANES D, PURDUE MP, ABNET CC et al. Prostate, Lung, Colorectal, and Ovarian Cancer Screening Trial Project Team. Serum Vitamin D concentration and prostate cancer risk: a nested case-control study. J Natl Cancer Inst 2008; 100: 796-804. http://dx.doi.org/10.1093/ jnci/djn152

[78] TONER CD, DAVIS CD, MILNER JA. The Vitamin D and cancer conundrum: Aiming at a moving target. J Am Diet 
Assoc 2010; 110: 1492-1500. http://dx.doi.org/10.1016/j. jada.2010.07.007

[79] NURNBERG B, GRABER S, GARTNER B, GEISEL J, PFOHLER C ET AL. Reduced serum 25-hydroxyVitamin D levels in stage IV melanoma patients., Anticancer Res 2009; 29: 3669-3674.

[80] MOAN J, POROJNICU AC, DAHLBACK A, SETLOW RB. Addressing the health benefits and risks, involving Vitamin D or skin cancer, of increased sun exposure. Proc Natl Acad Sci USA 2008; 105: 668-673. http://dx.doi.org/10.1073/ pnas.0710615105

[81] HOCHBERG Z, TEMPLETON AR. Evolutionary perspective in skin color, Vitamin D and its receptor. Hormones (Athens) 2010; 9: 307-311. http://dx.doi.org/10.14310/ horm.2002.1281

[82] THORNE J, CAMPBELL MJ The molecular cancer biology of the VDR.p 25-51. In: DL Trump, C.S. Johnson, (Eds), Vitamin D and Cancer. Springer, New York, USA, 2011, pp 342. ISBN 978-1-4419-7187-6. http://dx.doi.org/10.1007/978-1-44197188-3 2

[83] SZETO FL, SUN J, KONG J, DUAN Y, LIAO A et al. Involvement of the Vitamin D receptor in the regulation of NF-kappaB activity in fibroblasts. J Steroid Biochem Mol Biol 2007; 103: 563-6. http://dx.doi.org/10.1016/j.jsbmb.2006.12.092

[84] ZASLOFF M. Sunlight, Vitamin D, and the innate immune defenses of the human skin. J Invest Dermatol 2005; 125: xvixvii. http://dx.doi.org/10.1111/j.0022-202X.2005.23924.x

[85] NOLL DM, MASON TM, MILLER PS. Formation and repair of interstrand cross-links in DNA. Chem Rev 2006; 106: 277-301. http://dx.doi.org/10.1021/cr040478b

[86] PAWLOWSKA E, WYSOKINSKI D, BLASIAK J. Nucleotide Excision Repair and Vitamin D-Relevance for Skin Cancer Therapy. Int J Mol Sci. 2016; 17: 372. http://dx.doi.org/10.3390/ ijms 17040372

[87] DIXON KM, DEO SS, WONG G, SLATER M, NORMAN AW et al. Skin cancer prevention: a possible role of 1,25dihydroxyVitamin D3 and its analogs. J Steroid Biochem Mol Biol 2005; 97: 137-143. http://dx.doi.org/10.1016/j. jsbmb.2005.06.006

[88] WEBB AR, DECOSTA BR, HOLICK MF. Sunlight regulates the cutaneous production of Vitamin D3 by causing its photodegradation. J Clin Endocrinol Metab 1989; 68: 882-887. http://dx.doi.org/10.1210/jcem-68-5-882

[89] WEBB, AR, KLINE L, HOLICK MF. Influence of season and latitude on the cutaneous synthesis of Vitamin D3: Exposure to winter sunlight in Boston and Edmonton will not promote Vitamin D3 synthesis in human skin. J Clin Endocrinol Metab 1988; 67: 373-378.

[90] NELEMANS PJ, GROENENDAL H, KIEMENEY LA, RAMPEN FH, RUITER DJ etAal.AEffect of intermittent exposure to sunlight on melanoma risk among indoor workes and sun-sensitive individuals. Environ Health Perspect 1993; 101: 252-255. http://dx.doi.org/10.1289/ehp.93101252

[91] GANDINI S, SERA F, CATTARUZZA MS, PASQUINI P, PICCONI O et al. Meta-analysis of risk factors for cutaneous melanoma: II. Sun exposure. Eur J Cancer 2005; 41: 45-60. http://dx.doi.org/10.1016/j.ejca.2004.10.016
[92] CAINI S, GANDINI S, SERA F, RAIMONDI S, FARGNOLI $\mathrm{MC}$ et al. Metaanalysis of risk factors for cutaneous melanoma according to anatomical site and clinico-pathological variant. Eur J Cancer 2009; 45: 3054-3063. http://dx.doi.org/10.1016/j. ejca.2009.05.009

[93] NEWTON-BISHOP JA, CHANG YM, ELLIOTT F, CHAN $\mathrm{M}$, LEAKE $\mathrm{S}$ et al. Relationship between sun exposure and melanoma risk for tumours in different body sites in a large case-control study in a temperate climate. Eur J Cancer. 2011; 47: 732-741. http://dx.doi.org/10.1016/j.ejca.2010.10.008

[94] BATAILLE V, DE VRIES E. Melanoma - part 1: epidemiology, risk factors, and prevention. BMJ 2008; 337: a2249. http:// dx.doi.org/10.1136/bmj.a2249

[95] BROZYNA A, ZBYTEK B, GRANESE J, CARLSON AJ, ROSS $J$ et al. Mechanism of UV-related carcinogenesis and its contribution to nevi/melanoma. Expert Rev Dermatol 2007; 2: 451-469. http://dx.doi.org/10.1586/17469872.2.4.451

[96] ERDEI E, TORRES SM. A new understanding in the epidemiology of melanoma. Expert Rev Anticancer Ther 2010; 10: 1811-23. http://dx.doi.org/10.1586/era.10.170

[97] GODAR DE, LANDRY RJ, LUCAS AD. Increases UVA exposures and decreases cutaneous Vitamin $\mathrm{D}(3)$ may be responsible for the increasing incidence of melanoma. Med Hypotheses 2009; 72: 434-443. http://dx.doi.org/10.1016/j. mehy.2008.09.056

[98] GORMAN S, KURITZKY LA, JUDGE MA, DIXON KM, MCGLADE JP et al. Topically applied 1,25dihydroxyVitamin D3 enhances the suppressive activity of CD4+CD25+ cells in the draining lymph nodes. J Immunol 2007; 179: 6273-6283. http://dx.doi.org/10.4049/jimmunol.179.9.6273

[99] MASON RS, SEQUEIRA VB, DIXON KM, GORDONTHOMSON C, POBRE $\mathrm{K}$ et al.Photoprotection by 1alpha,25dihydroxyVitamin D and analogs:further studies on mechanisms andimplications for UV-damage. J Steroid Biochem Mol Biol 2010; 121: 164-168. http://dx.doi.org/10.1016/j. jsbmb.2010.03.082

[100] BERWICK, M., ARMSTRONG, BK, BEN-PORAT, L., FINE, J., KRICKER et al. Sun exposure and mortality from melanoma. J Natl Cancer Inst 2005; 97: 195-199. http://dx.doi.org/10.1093/ inci/dji019

[101] FIELD S, DAVIES J, BISHOP DT, NEWTON-BISHOP JA. Vitamin D and melanoma, Dermatoendocrinol 2013; 5: 121-129. http://dx.doi.org/10.4161/derm.25244

[102] BISHOP DT, DEMENAIS F, ILES MM, HARLAND M, TAYLOR JC et al. Genome-wide association study identifies three loci associated with melanoma risk. Nat Genet 2009; 41: 920-925. http://dx.doi.org/10.1038/ng.411

[103] DOWNING, A., YU, X.Q., NEWTON-BISHOP, J., FORMAN, D. Trends in prognostic factors and survival from cutaneous melanoma in Yorkshire, UK and New South Wales, Australia between 1993 and 2003. Int J Cancer 2008; 123: 861-866. http://dx.doi.org/10.1002/ijc.23495

[104] NEWTON-BISHOP JA, BESWICK S, RANDERSON-MOOR J, CHANG YM, AFFLECK P et al. Serum 25-hydroxyVitamin D3 levels are associated with breslow thickness at presentation and survival from melanoma. J Clin Oncol 2009; 27: 5439-5444. http://dx.doi.org/10.1200/JCO.2009.22.1135 
[105] GANDINI S, FRANCESCO F, JOHANSON H, BONANNI B, TESTORI A. Why Vitamin D for cancer patients? Ecancermedicalscience. 2009; 3: 160.

[106] DE LUCA HF. Evolution of our understanding of Vitamin D. Nutrition Rewiews 2008; 66: 73-87. http://dx.doi.org/10.1111/ j.1753-4887.2008.00105.x

[107] HOLICK MF. Vitamin D: A D-lightful solution for health. J Investig Med 2011; 59: 872-880. http://dx.doi.org/10.2310/ IIM.0b013e318214ea2d

[108] WEBB AR. Who, what, where and when-influences on cutaneous Vitamin D synthesis. Prog Biophys Mol Biol 2006; 92: 17-25. http://dx.doi.org/10.1016/j. pbiomolbio.2006.02.004

[109] TANG JY, FU T, LAU C, OH DH, BIKLE DD et al. Vitamin D in cutaneous carcinogenesis: part II. J Am Acad Dermatol 2012; 67: 817. http://dx.doi.org/10.1016/j.jaad.2012.05.044

[110] FIELD S, NEWTON-BISHOP JA. Melanoma and Vitamin D. Mol Oncol 2011; 5: 197-214. http://dx.doi.org/10.1016/j. molonc.2011.01.007

[111] GANDINI S, RAIMONDI S, GNAGNARELLA P, DORÉ JF, MAISONNEUVE P et al. Vitamin D and skin cancer: a meta-analysis. Eur J Cancer 2009; 45: 634-41. http://dx.doi. org/10.1016/j.ejca.2008.10.003

[112] FLYNN A, HIRVONEN T, MENSINK GB, OCKE MC, SERRAMAJEM L et al. Intake of selected nutrients from foods, from fortification and from supplements in various European countries. Food Nutr Res. 2009; 53: 10. http://dx.doi. org/10.3402/fnr.v53i0.2038

[113] PLUM LA, PRAHL JM, MA X, SICINSKI RR, GOWLUGARI $S$ et al. Biologically active noncalcemic analogs of 1alpha,25dihydroxyVitamin D with an abbreviated sidechain containing no hydroxyl. Proc Natl Acad Sci U S A. 2004; 101: 6900-6904. http://dx.doi.org/10.1073/ pnas.0401656101

[114] MURARI MP, LONDOWSKI JM, BOLLMAN S, KUMAR R. Synthesis and biological activity of 3 beta-hydroxy-9,10secopregna-5,7,10[19]-triene-20-one: a side chain analogue of Vitamin D3. J Steroid Biochem. 1982; 17: 615-619. http:// dx.doi.org/10.1016/0022-4731(82)90562-3

[115] HOLICK MF, GARABEDIAN M, SCHNOES HK, DELUCA HF. Relationship of 25-hydroxyVitamin D3 side chain structure to biological activity. J Biol Chem 1975; 250: 226-230.
[116] ZMIJEWSKI MA, LI W, CHEN J, KIM T-K, ZJAWIONY JK et al. Synthesis and photochemical transformation of $3 \beta, 21-$ dihydroxypregna-5,7-dien-20-one to novel secosteroids that show anti-melanoma activity. Steroids. 2011; 76: 193-203. http://dx.doi.org/10.1016/j.steroids.2010.10.009

[117] SLOMINSKI AT, BROZYNA A, JOZWICKI W, TUCKEY RC. Vitamin D as an adjuvant in melanoma therapy. Melanoma Manag 2015; 2: 1-4. http://dx.doi.org/10.2217/mmt.14.36

[118] AGMON-LEVIN N, THEODOR E, SEGAL RM, SHOENFELD Y. Vitamin D in systemic and organ-specific autoimmune diseases. Clin Rev Allergy Immunol 2013; 45: 256-266. http://dx.doi.org/10.1007/s12016-012-8342-y

[119] GOUNI-BERTHOLD I, KRONE W, BERTHOLD HK. Vitamin D and cardiovascular disease. Curr Vasc Pharmacol 2009; 7: 414-422. http://dx.doi.org/10.2174/157016109788340686

[120] MANGIN M, SINHA R, FINCHER K. Inflammation and Vitamin D: the infection connection. Inflamm Res 2014; 63: 803-819. http://dx.doi.org/10.1007/s00011-014-0755-Z

[121] WU X, ZHOU T, CAO N, NI J, WANG X. Role of Vitamin D Metabolism and Activity on Carcinogenesis. Oncol Res 2014; 22: 129-137. http://dx.doi.org/10.3727/096504015X $\underline{14267282610894}$

[122] TUOHIMAA P. Vitamin D and aging. J Steroid Biochem Mol Biol 2009; 114: 78-84. http://dx.doi.org/10.1016/j. jsbmb.2008.12.020

[123] DONAWHO C, MULLER H, BUCANA C, KRIPKE M. Enhanced growth of murine melanoma in ultraviolet-irradiated skin is associated with local inhibition of immune effector mechanisms. J Immunol 1996; 157: 781-786.

[124] NESS RA, MILLER DD, LI W. The role of Vitamin D in cancer prevention. Chin J Nat Med 2015; 13: 481-497. http://dx.doi. org/10.1016/s1875-5364(15)30043-1

[125] LARRIBA MJ, MUNOZ A MECHANISMS OF RESISTENCE TO VITAMIN D ACTION IN HUMAN CANCER CELLS. p 325-332. In: MF Holick (Ed). Vitamin D: physiology, molecular biology and clinical applications. Humana Press, 2010, pp 1160. ISBN 978-1-60327-300-8. http://dx.doi. org/10.1007/978-1-60327-303-9 15

[126] REICHRATH J, REICHRATH S, HEYNE K, VOGT T, ROEMER K. Tumor suppression in skin and other tissues via cross-talk between Vitamin D and p53-signaling. Front Physiol. 2014; 5: 166. http://dx.doi.org/10.3389/fphys.2014.00166 